JPPUMA: Jurnal Ilmu Pemerintahan dan Sosial Politik UMA (Journal of Governance and Political Social UMA), 8 (1) (2020): 74-83, DOI: https://doi.org/10.31289/ippuma.v8i1.3159

JPPUMA: Jurnal IImu Pemerintahan dan Sosial Politik UMA (Journal of Governance and Political Social UMA)

Available online http://ojs.uma.ac.id/index.php/jppuma

\title{
Financial Management of Indonesian Democratic Party- Struggle (Partai Demokrasi Indonesia-Perjuangan/PDPI) in The District of Jepara and Efforts in Increasing Public Trust
}

\author{
Farich Azhar \& Kushandajani \\ Master of Political Science Study Program, Faculty of Social and Political Sciences \\ Universitas Diponegoro, Indonesia
}

Recieved: December 03, 2019; Accepted: January 22, 2020; Published: June 2020

\begin{abstract}
This study aims to know the financial management of the Indonesian Democratic Party-Struggle (Partai Demokrasi Indonesia-Perjuangan) in the District of Jepara Regency and its connection to public trust. The financial management in the party determines its existence and electability in the political field. To increase the party's electability and to maintain the confidence of its members and public trust, financial transparency should be improved. Financial transparency of the political party is still beyond the expectations. Ideally, as a public institution, Indonesian political parties have a very large role in maintaining democracy and good governance. This research investigates the Branch (Dewan Pimpinan Cabang) of the Indonesian Democratic Party-Struggle (PDI-P) in the district of Jepara, Central Java. This party won the 2014 General Election in the district. Although, its financial management is not transparent. This research applies quantitative methods to portray the phenomenon. This research chose 100 people as samples from the total population of the Jepara District who has the right to vote. The sample has been taken by probability sampling techniques. The results show that DPC-PDIP in Jepara District manages its finance with discipline and following law. PDIP is considered to know about good financial reporting. This increases public trust and the party's confidence.

Keywords: Financial Management, Political Parties, Public Trust
\end{abstract}

How to Cite: Azhar, F \& Kushandajani. (2020). Financial Management of Indonesian Democratic PartyStruggle (Partai Demokrasi Indonesia-Perjuangan/PDPI) in the District of Jepara and Efforts in Increasing Public Trust. JPPUMA: Jurnal Ilmu Pemerintahan dan Sosial Politik UMA Uournal of Governance and Political Social UMA), 8(1): 74-83

*Corresponding author:

E-mail: farich_azhar92@yahoo.com
ISSN 2549-1660 (Print)

ISSN 2550-1305 (Online) 


\section{INTRODUCTION}

Political parties are designed to influence the quality of public policy in certain ideological interests. The parties work to affect the policy-making through the distribution of the influence or directly by using power gained through public participation in electoral activities. Political parties have duties and authority or rights and obligations in political structures, through which they head to achieve their goals in a political system. Ideally, they are expected to bring wealth and increase public trust.

Political party's funding activities are generally carried out through membership fees. However, in its development, the need for funds in political campaigning activities seems to be even greater. Therefore, a strong democratic political system requires political parties not only functional and democratic, both internally and externally, but also well institutionalized and competitive (Surbakti \& Supriyanto, 2011).

To increase the political party's electability and to maintain the confidence of party members and public trust, the party's financial transparency is necessary. To that end, the government formulated a law regulating the financial management of political parties based on the principles of transparency and accountability. Law No. 2 of 2011 is a substitute for Law No. 2 of 2008 emphasizing that political parties are obliged to submit accountable reports on revenues and expenditures sourced from the national budget (APBN) and regional budget (APBD) to the financial auditory body (BPK) regularly once a year.

However, Indonesia Corruption Watch (ICW) reveals that during 2014 there were 629 corruption cases and as many as 1,328 suspects causing state losses of Rp. 5,29 trillion. The cases increased by 69 cases compared to 2013, namely 560 corruption cases which caused losses of $\mathrm{Rp} 7.3$ Trillion of the state's money, where the cases are dominated by political elites (Khairudin \& Erlanda, 2016). Further, the government's assertiveness needs to be questioned, because there are no sanctions for political parties that do not prepare financial reports. Meanwhile, Law No. 2 of 2008 and Law No. 2 of 2011 provide leeway for oversight of political party finances that is, increasing the nominal amount of donations both individuals and business entities. However, the mechanism for submitting financial statements is not mentioned in the law (Permadi \& Riharjo, 2015).

The issue of transparency over political party funding is still challenging currently so party financial regulation is needed to achieve transparency and accountability. Public participation in financial management such as getting access to financial documents is still very difficult to guarantee. Transparency in political party financial management is still far from expectations. Even though, as a public institution, political parties have a very large role in maintaining democracy and governance. Financial management in the party internally determines the existence and electability of the party in politics.

In the constellation of General Election at the regional level, especially in Jepara Regency, PDIP obtained the second most votes of 113,769 based on the recapitulation of the Jepara Regency Election Commission in 2014 (KPU Jepara, 2014). The first majority vote in Jepara Regency was PPP with 120,990 votes that are followed by other parties. The recapitulation shows that the difference in votes between PPP as the winner of the election in the Jepara Regency is not far from PDIP. So PDIP is classified as a big party in the regency. As a big party, it needs to be viewed in terms of party financial management and its influence on the vote in the 2014 election.

Besides the predicate as a major party in Jepara Regency, PDIP was 
included in the ranks of the party which was the most corrupt as Corruption Eradication Commission (KPK) in the course 2002-2014. As a party included in the top 3 parties, it is very likely to commit criminal acts of corruption. However, the predicate of the most corrupt party shows that poor accountability and financial transparency do not seem to influence a party winning the election. The following figure shows the case.

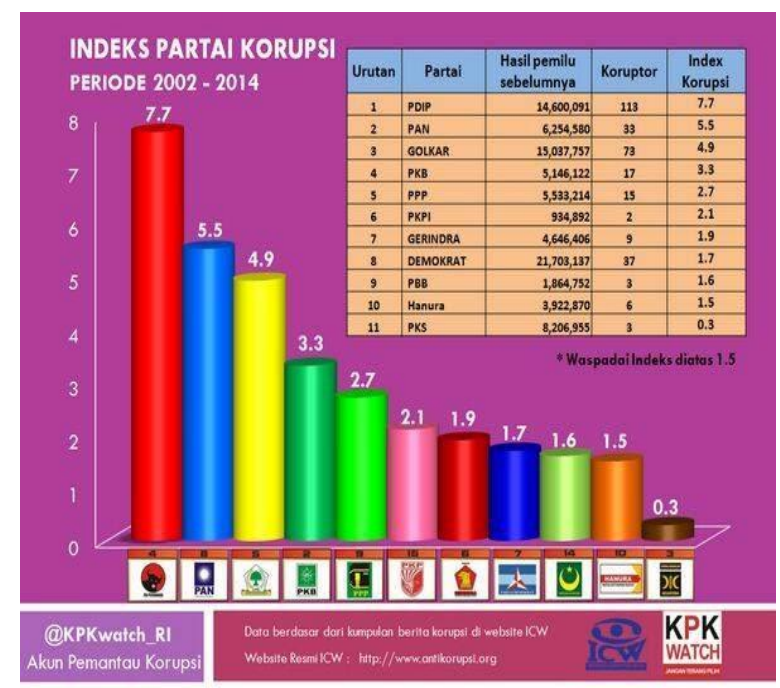

Figure 1 Corruption Index of political parties during 2002-2014.

Source: (ICW, 2014)

The above chart illustrates that it is necessary to conduct a more comprehensive study on the correlation between the financial transparency of political parties and public trust. Several previous studies that examine the financial transparency of political parties have a different focus, such as, the research by Sekar Anggun Gading Pinilih titled "Encouraging Transparency and Accountability of Political Parties Financial Arrangements" (Pinilih, 2017). Bagus Permadi and Ikhsan Budi Riharjo studied the same topic titled "The View of Party Management Towards Transparency and Accountability in Political Party Financial Reporting" (Permadi \& Riharjo, 2015). Eka Adhi Wibowo's research is titled "Accountability of Political Parties and
Electability of Political Parties: A Case Study of Election Contesting Political Parties in DIY Province in 2014" (Wibowo, 2018).

Furthermore, Mayki Ayu Juliestari has done research titled "Disclosure of Party Financial Responsibility as the Basis for Good Political Party Governance: Study of the Democratic National Party, the National Awakening Party, the National Mandate Party and the Prosperous Justice Party of Gowa Regency" (Lestari, 2018). Moreover, Alfian Ibnu Sina has studied the topic in research titled "Implementation of Transparency and Accountability as Corruption Prevention Measures: Study on PKB DPC in Ngawi" (Sina, 2017). Masiyah Kholmi's research is titled "Constituent Perceptions of Financial Accountability of Political Parties: Studies in Malang City" (Kholmi, 2010). Rohmah's study is titled "UNESA Accounting Student Perceptions About the Effects of Transparency and Financial Accountability of Political Parties on Party Performance and Efforts to Eradicate White Collar Crime" (Rohmah, 2014). The last is Yusuf Eko Nahuddin's research titled "Financial Accountability of Political Parties Towards Good Political Party Governance" (Nahuddin, 2015).

This study takes a different focal point from previous studies by emphasizing the Financial Management of the Indonesian Democratic Party of Struggle in the Jepara Regency as an Effort to Increase Public Trust. Based on the background of the problems and conditions discussed above, the research question that will be raised in this study is how does the influence of the Financial Management of PDIP in the Jepara Regency on Public Trust. This study aims to seek to know the financial management of the Indonesian Democratic Party of Struggle (PDIP) of Jepara Regency on the level of public trust.

Political parties are designed to influence the quality of public policy in certain ideological interests. The parties 
work to affect the policy-making through the distribution of the influence or directly by using power gained through public participation in electoral activities. Political parties have duties and authority or rights and obligations in political structures, through which they head to achieve their goals in a political system. Ideally, they are expected to bring wealth and increase public trust.

Political party's funding activities are generally carried out through membership fees. However, in its development, the need for funds in political campaigning activities seems to be even greater. Therefore, a strong democratic political system requires political parties not only functional and democratic, both internally and externally, but also well institutionalized and competitive (Surbakti \& Supriyanto, 2011).

To increase the political party's electability and to maintain the confidence of party members and public trust, the party's financial transparency is necessary. To that end, the government formulated a law regulating the financial management of political parties based on the principles of transparency and accountability. Law No. 2 of 2011 is a substitute for Law No. 2 of 2008 emphasizing that political parties are obliged to submit accountable reports on revenues and expenditures sourced from the national budget (APBN) and regional budget (APBD) to the financial auditory body (BPK) regularly once a year.

However, Indonesia Corruption Watch (ICW) reveals that during 2014 there were 629 corruption cases and as many as 1,328 suspects causing state losses of Rp. 5,29 trillion. The cases increased by 69 cases compared to 2013, namely 560 corruption cases which caused losses of $\mathrm{Rp} \mathrm{7.3} \mathrm{Trillion} \mathrm{of} \mathrm{the} \mathrm{state's}$ money, where the cases are dominated by political elites (Khairudin \& Erlanda, 2016). Further, the government's assertiveness needs to be questioned, because there are no sanctions for political parties that do not prepare financial reports. Meanwhile, Law No. 2 of 2008 and Law No. 2 of 2011 provide leeway for oversight of political party finances that is, increasing the nominal amount of donations both individuals and business entities. However, the mechanism for submitting financial statements is not mentioned in the law (Permadi \& Riharjo, 2015).

The issue of transparency over political party funding is still challenging currently so party financial regulation is needed to achieve transparency and accountability. Public participation in financial management such as getting access to financial documents is still very difficult to guarantee. Transparency in political party financial management is still far from expectations. Even though, as a public institution, political parties have a very large role in maintaining democracy and governance. Financial management in the party internally determines the existence and electability of the party in politics.

In the constellation of General Election at the regional level, especially in Jepara Regency, PDIP obtained the second most votes of 113,769 based on the recapitulation of the Jepara Regency Election Commission in 2014 (KPU Jepara, 2014). The first majority vote in Jepara Regency was PPP with 120,990 votes that are followed by other parties. The recapitulation shows that the difference in votes between PPP as the winner of the election in the Jepara Regency is not far from PDIP. So PDIP is classified as a big party in the regency. As a big party, it needs to be viewed in terms of party financial management and its influence on the vote in the 2014 election.

Besides the predicate as a major party in Jepara Regency, PDIP was included in the ranks of the party which was the most corrupt as Corruption Eradication Commission (KPK) in the course 2002-2014. As a party included in 
the top 3 parties, it is very likely to commit criminal acts of corruption. However, the predicate of the most corrupt party shows that poor accountability and financial transparency do not seem to influence a party winning the election. The following figure shows the case.

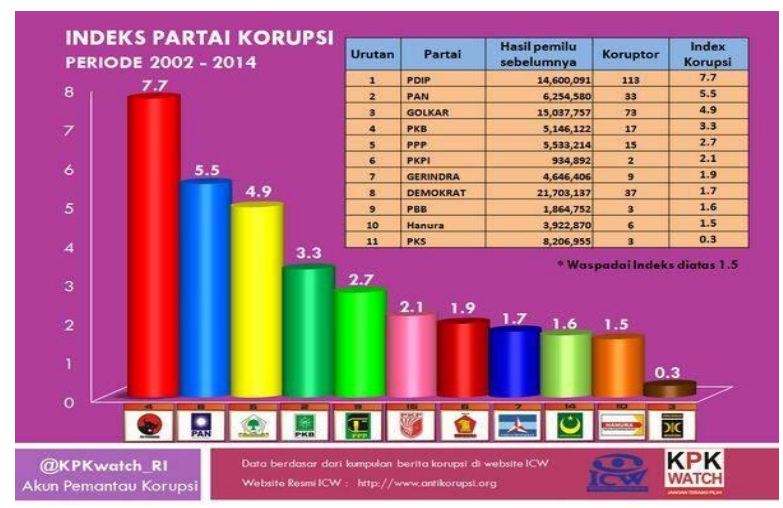

Figure 2. Corruption Index of political parties during 2002-2014.

Source: (ICW, 2014)

The above chart illustrates that it is necessary to conduct a more comprehensive study on the correlation between the financial transparency of political parties and public trust. Several previous studies that examine the financial transparency of political parties have a different focus, such as, the research by Sekar Anggun Gading Pinilih titled "Encouraging Transparency and Accountability of Political Parties Financial Arrangements" (Pinilih, 2017). Bagus Permadi and Ikhsan Budi Riharjo studied the same topic titled "The View of Party Management Towards Transparency and Accountability in Political Party Financial Reporting" (Permadi \& Riharjo, 2015). Eka Adhi Wibowo's research is titled "Accountability of Political Parties and Electability of Political Parties: A Case Study of Election Contesting Political Parties in DIY Province in 2014" (Wibowo, 2018).

Furthermore, Mayki Ayu Juliestari has done research titled "Disclosure of Party Financial Responsibility as the Basis for Good Political Party Governance: Study of the Democratic National Party, the National Awakening Party, the National Mandate Party and the Prosperous Justice Party of Gowa Regency" (Lestari, 2018). Moreover, Alfian Ibnu Sina has studied the topic in research titled "Implementation of Transparency and Accountability as Corruption Prevention Measures: Study on PKB DPC in Ngawi" (Sina, 2017). Masiyah Kholmi's research is titled "Constituent Perceptions of Financial Accountability of Political Parties: Studies in Malang City" (Kholmi, 2010). Rohmah's study is titled "UNESA Accounting Student Perceptions About the Effects of Transparency and Financial Accountability of Political Parties on Party Performance and Efforts to Eradicate White Collar Crime" (Rohmah, 2014). The last is Yusuf Eko Nahuddin's research titled "Financial Accountability of Political Parties Towards Good Political Party Governance" (Nahuddin, 2015).

This study takes a different focal point from previous studies by emphasizing the Financial Management of the Indonesian Democratic Party of Struggle in the Jepara Regency as an Effort to Increase Public Trust. Based on the background of the problems and conditions discussed above, the research question that will be raised in this study is how does the influence of the Financial Management of PDIP in the Jepara Regency on Public Trust. This study aims to seek to know the financial management of the Indonesian Democratic Party of Struggle (PDIP) of Jepara Regency on the level of public trust.

In the reform era, the democratic system began to be implemented well. Most importantly, the electoral system allows the president to be directly elected, no longer elected through the People's Consultative Assembly. This study describes the general election after postreform until now. 


\section{RESEARCH METHOD}

This research uses descriptive quantitative methods to explain a phenomenon or social reality. The phenomenological approach aims to understand respondents on the existence of humans or society, as well as their experiences in social interaction (Tuasikal, 2013). The phenomenological approach in this study aims to define the research problem based on an empirical study such as observations.

The objects of this study are the Branch Representative Council (DPC) PDI Perjuangan in Jepara Regency and the people of the Jepara Regency. The sample is part of the population with certain characteristics and has been chosen. The population in this study were all Jepara Regency residents who already had the right to vote, amounting to 858,209 people (KPU Jepara, 2018). The authors narrowed the population by calculating sample sizes carried out by the Slovin technique (Sugiyono, 2011). Consideration using the Slovin formula because the number of samples drawn must be representative so research results can be generalized. Moreover, the calculations do not require a table of the number of samples, but rather can be done with formulas and simple calculations.

The Slovin formula determining samples is as following:

$$
\mathbf{n}=\frac{N}{1+N(e)^{2}}
$$

Information:

$\mathrm{n}=$ Sample size / number of respondents

$\mathrm{N}=$ population size

$\mathrm{E}=$ Percentage of looseness

The population of this study is 856,538 people. The percentage of allowance used is 10 percent and the calculation can be fulfilled to achieve compatibility. Then to find out the number of research samples carried out calculations as follows:

$$
\begin{aligned}
& n=\frac{856,538}{1+856,538(0,1)^{2}} \\
& n=\frac{856,538}{8,566} \\
& n=\begin{array}{l}
99,9 \text { adjusted to respondents to } \\
\text { become } 100
\end{array}
\end{aligned}
$$

Based on the above calculation, the sample of respondents in this study was adjusted to 100 people. They are the residents of Jepara Regency who already had the right to vote. Samples were taken based on probability sampling techniques; simple random sampling.

Sampling was done by coincidental technique, in which the sample is determined by coincidences. Anyone who coincidentally meets with a researcher can be taken into consideration as a sample. If the person whom the researcher encountered by chance meets the criteria, he or she can be used as a respondent (Sugiyono, 2011).

The statistical " $\mathrm{t}$ " test is managed to find out how much influence the independent variable has on the dependent variable partially. Here is the research Hypothesis:

\section{Ho: Financial management of political parties influences public trust}

Ha: political party financial management has no impact on public trust

The hypothesis acceptance criteria are if the $t$ count $<t$ table with an error rate ( $\alpha) 0.05$, the independent variable has a significant effect on the dependent variable. Meanwhile, if $\mathrm{t}$ count $\geq \mathrm{t}$ table with an error rate $(\alpha) 0.05$, the independent variable does not have a significant effect on the dependent variable.

In this study, quantitative descriptive research has been carried out by collecting data. Then, the data have been analyzed through quantitative descriptive data analysis. The analysis consists of two activities, namely, data presentation and 
concluding (Sugiyono, 2011). The presentation of data can be interpreted as a collection of numerical data and arranged tables that provide the possibility of concluding. The presentation of data in quantitative research is usually presented in the form of numerical tables that are equipped with matrices, charts, and graphs. The presentation of data is also part of the analysis process. Subsequently, the final step is drawing conclusions and verification. Initial conclusions are temporary and will change if no valid evidence is found. However, if the initial conclusions are supported by valid and consistent evidence, the conclusions are credible. Conclusions were also verified during the study. The meanings that emerge from the data must be tested for their correctness and their suitability. If this is not the case, then, what has been done to conclude is something unclear.

chose respondents through the technique of simple random sampling. The author collected data from two main sources. First, the primary data collected by questionnaires as the instrument. Second, the secondary data obtained through published sources, such as books, journals, research reports, documents, and other written materials related to this topic. The author applies the theory of the cognitive domain model developed by Newman \& Sheth (1985). The variable test uses the multinomial logistic regression analysis. With the equation $g_{j}(x)=\beta_{j 0}+\beta_{j 1} x_{1}+\beta_{j 2} x_{2}+\ldots+\beta_{j p} x_{p}$ and 0,05 significance level and a 95 percent confidence level.

\section{RESULT AND DISCUSSION}

The characteristics of respondents in this study were divided into four sections based on gender, age, education level, and occupation. Data from the field refers to the character of respondents at the sex level. Women are more in terms of quantity or quantity compared to men. As many as 64 of 100 women were studied or
64 percent of women, while 36 out of 100 respondents were men or 36 percent of the total respondents. The general category, respondents are dominated by people who are 41-50 years age, which form 47 percent of the 100 respondents studied. Whereas there are 30 people in the age of $30-40$ years old are or 30 percent of the total interviewed respondents. Respondents who are below 30 years old are only 13 percent of the 100 respondents. Characteristics of respondents based on education level are that as many as 52 respondents or 52 percent of the respondents went to high school, 34 percent of 100 respondents studied until the Bachelor degree. Characteristics of respondents based on the occupation are that as many as 49 respondents or 49 percent of 100 respondents examined. The people who work in the agricultural sector are 17 percent and those who work as civil servants are 24 percent.

The results of respondents in seeing opinions about the obligations of political parties make an annual report shows 39 percent strongly agree, 31 percent agree, 22 percent disagree, and 8 percent strongly disagree. Based on these data, the public believes that political parties such as DPC PDIP Jepara Regency always compile annual reports as a form of party's accountability to the public. This is evidenced by the answers of 70 percent of respondents who know this, while 30 percent did not agree that the party made financial reports. Meanwhile, respondents' opinions about transparency and accountability of political party cash flow reports were obtained, in which 33 percent strongly agreed, 37 percent agreed, 23 percent disagreed and 7 percent strongly disagreed. This means that the public believes that the DPC PDIP of Jepara Regency is considered transparent in carrying out cash flow reports. This can be seen from 70 percent of respondents who think the party must 
be transparent and accountable about financial statements.

Although the financial statements submitted are closed to the public and only submitted to the DPC executive, the community is informed that every institution that takes funding comes from the state or the government must compile reports on the use of these funds, including political parties. Statements of cash flows, the preparation of financial statements of political parties must comply with applicable accounting standards. Respondents' opinions about the suitability of financial statements with applicable accounting standards are that 32 percent strongly agree, 47 percent agree, 13 percent disagree, and 8 percent strongly disagree. The public believes that the party must make a report based on applicable standards so that it can be accounted for. It can be viewed from 79 percent of respondents who agreed on the suitability.

Public trust in (PDIP) is seen in two dimensions of ability and integrity to see public opinion about managing the party's finances. Regarding the ability, the opinion of respondents shows, firstly about the adequacy of political party competencies in financial management, in which 19 percent strongly agree, 47 percent agree, 20 percent disagree, and 14 percent strongly disagree. Most of the respondents agreed that DPC PDIP in Jepara Regency has the ability in managing party finances. This was proven by 66 percent of respondents agreeing to it. The community admits that their trust is based on their experience when interacting with PDIP cadres in Jepara Regency.

Meanwhile, respondents' opinions about the adequacy of political party experience in financial management were obtained, 8 percent strongly agreed, 59 percent agreed, 22 percent disagreed, and 11 percent strongly disagreed. This means that the community assesses that the PDIP in Jepara Regency has sufficient experience in managing political parties' finance as seen from 67 percent of respondents who agree and only 33 percent who disagree. These data reinforce the public's trust in the party especially PDIP Jepara Regency in managing finances. In line with this, respondents' opinions about party financial management through legal and legal mechanisms show that 24 percent strongly agree, 40 percent agree, 24 percent disagree and 12 percent strongly disagree. This means that 64 percent of respondents believe that PDIP financial statements are carried out under the prevailing procedural mechanism. This is inseparable from the knowledge of party members in the financial reporting mechanism that is considered competent and appropriate. This opinion was strengthened by the opinions of respondents about the political party's ability in managing the financial statements, in which 17 percent strongly agreed, 42 percent agreed, 32 percent disagreed, and 9 percent strongly disagreed. As a joint party, the community valued their knowledge based on experience and learning, so that respondents considered knowledge about the financial statements of PDIP Perjuangan in Jepara Regency to be very good.

It is the dimension of integrity in questioning the party's financial statements regarding the party's financial statements considered reasonable without manipulation, in which respondents' opinions show that 18 percent strongly agree, 51 percent agree, 22 percent disagree, 9 percent strongly disagree. The data shows that most respondents have the perception that the financial management report prepared by DPC PDIP Jepara Regency did not experience manipulation in its composition and can be justified. While in seeing the transparency of information in the party's financial statements, respondents rated 15 percent strongly agree, 53 percent agreed, 20 
percent disagreed, and 12 percent strongly disagreed. This means that DPC PDIP in Jepara Regency has fulfilled the community's need for information disclosure and transparency in financial reports.

High public confidence in indicators of information disclosure is in line with the opinions of respondents regarding reliable and trustworthy financial statements. It can be seen from the respondents, in which 20 percent strongly agree, 46 percent agree, 24 percent disagree, 10 percent strongly disagree. This means that the public does not doubt the ability of DPC PDIP Perjuangan in the Jepara Regency in the financial statements. The community believes that the financial statements of political parties have been prepared honestly and can be accounted for 62 percent of those who agreed and 38 percent disagreed. This means that political parties must prioritize honesty in every report. In this case, DPC PDIP Perjuangan proves that the financial statements reported are very accountable and responsible.

In general, respondents' trust in the financial management of political parties shows that 61 percent believed and 39 percent did not. PDIP of Jepara Regency was considered by the public to be very good in financial statements. This was supported by public acceptance of the party's financial management report as a form of public accountability, in which 71 percent agreed and 29 percent disagreed.

Furthermore, this discussion takes a look at regression analysis to find out how much influence the political party financial management variables have on public trust in the PDIP Party in Jepara Regency, as the following table shows.

\begin{tabular}{|c|c|c|c|c|}
\hline & Model & Coefisien & $\mathrm{t}$ & $\begin{array}{c}\text { Probability } \\
\text { of error }\end{array}$ \\
\hline 1 & (Constant) & 0,151 & 0,625 & 0,000 \\
\hline & $\begin{array}{l}\text { Financial } \\
\text { Management of } \\
\text { Political Parties } \\
\text { (X) }\end{array}$ & 0,940 & 10,819 & 0,000 \\
\hline
\end{tabular}

The regression results in the above table have been obtained from the following regression equation:

$\wedge$ Public Trust $(\mathrm{Y})=0,151+0,940(\mathrm{X})$ The number resulting from the equation can be explained as follows:

a. The value of the Constanta (a) is 0.151. This means that if the independent variable is assumed to be zero (0), then Public Trust is 0.151 .

b. The regression coefficient value of the Political Party Financial Management variable is 0.940 . This means that each increase in the quality of financial management of a political party by 1 unit will increase public confidence by 0.940 .

The statistical test sees that the independent variable has a t-count greater than $t$ table that is 1,660 . So at a significant level of 5 percent, partially the financial management variables of political parties have a significant influence on public confidence in DPC PDIP Jepara Regency.

PDIP Perjuangan has been predicated as a big party in Jepara Regency. However, it is included as a political party which was the most corrupt by KPK during the period between 2002 and 2014. This did not reduce public confidence in this party. Professionally managed finance, although less transparent, does not undermine public confidence in the party. SPPS test results show that variable political management of political parties (X) and Public trust variables have a significant effect. This means that the better financial management of political parties will increase public confidence in Jepara Regency.

\section{CONCLUSION}

DPC PDIP Jepara Regency has reported ist financial management with discipline and following applicable laws and regulations. The compiled financial statements are under accounting standards based on Law no 2 and Law. No. 3 of 1999. While accounting standards are 
guided by PSAK 45 issued by the Indonesian Accounting Association or IAI.

Related to public trust, the community believes that DPC PDIP Jepara Regency has the ability in financial management and knowledge about reporting. The party has also reasonable financial reports without manipulation. In this aspect, the community still believes that political parties have information disclosure to the public related to party financial management. Further, the community believes that the PDP of Jepara Regency is honest and can be accounted for in managing party finances. As the statistical test results show that financial management has influence significantly public trust. As having been tested, Hypothesis $(\mathrm{H})$, which is the variable of financial management of political parties, has been proven to have a positive and significant effect on public trust in DPC PDIP Jepara Regency.

\section{BIBLIOGRAPHY}

ICW. (2014). Laporan akhir tahun ICW 2014. Antikorupsi. Jakarta 26 Mei. HIm 23. Diaksesdari antikorupsi.org.

Juliestari, A.M. (2018). Pengungkapan Pertanggungjawaban Keuangan Partai Sebagai Dasar Good Political Party Governance. Skripsi. Universitas Islam Negeri Alaudin Makasar.

Khairudin \& Erlanda, R. (2016). Pengaruh Transparansi Dan Akuntabilitas Laporan Keuangan Pemerintah Daerah (LKPD) Terhadap Tingkat Korupsi Pemerintah Daerah (Studi Pada Pemerintah Kota Sesumatra). Jurnal Akuntansi \& Keuangan. 7 (2) : 137-140.

Kholmi, M. (2010). Persepsi Konstituen terhadap Akuntabilitas Keuangan Partai Politik: Studi Di Kota Malang. Jurnal AKuntansi Multiparadigma.1 (2) : 207- 222.
KPU Jepara. (2018). KPU Jepara Tetapkan DPT Pemilu 2019 Sebanyak 858.209. Jepara 20 Agustus. Hlm 1. Diakses dari www.Kpujepara.go.id

KPU Jepara . (2014). Rekapitulasi Jumlah Perolehan Suara Sah Partai Politik Dalam Pemilu Anggota DPRD Kabupaten/Kota Tahun 2014. Jepara 20 April. Hlm 1. Diakses dari www.Kpujepara.go.id.

Nahuddin, E. Y. (2015). Pertanggungjawaban Keuangan Partai Politik Menuju Tata Kelola Partai Politik Yang baik. Jurnal Cakrawala Hukum. 6 (2) : 276-292.

Permadi, B., \& Riharjo, B.I. (2015). Pandangan Pengurus Partai Terhadap Transparansi Dan Akuntabilitas Dalam Pelaporan Keuangan Partai Politik. Jurnal Ilmu \& Riset Akuntansi. 4 (7) : 3-6.

Pinilih, G.A.S. (2017). Mendorong Transparansi dan Akuntabilitas Pengaturan Keuangan Partai. Jurnal Mimbar Hukum. 29 (1) : 69-81.

Rohmah, L. (2014). Persepsi Mahasiswa Akuntansi UNESA Tentang Pengaruh Transparansi Dan Akuntabilitas Keuangan Partai Politik Terhadap Kinerja Partai Dan Upaya Pemberantasan Kejahatan Kerah Putih. Jurnal Akuntansi AKUNESA. 2 (2) : 1-23.

Sina, I.A. (2017). Implementasi Transparansi Dan Akuntabilitas Sebagai Upaya Mencegah Korupsi: Studi Pada DPC PKB Kabupaten Ngawi. Skripsi. Institut Agama Islam Negeri Surakarta.

Sugiyono. (2011). Metode Penelitian Kuantitatif, Kualitatif dan R\&D. Bandung : Alfabeta.

Surbakti, R. \& Supriyanto, D. (2011). Pengendalian Keuangan Partai Politik. Jakarta Selatan: Kemitraan Bagi Pembaruan Tata Pemerintahan.

Tausikal, A. (2013). fenomenologis Perencanaan dan Penganggaran Pemerintah Daerah. Jurnal Akutansi Universitas Jember. 11(2): 78-91

Wibowo, A.E. (2018). Akuntabilitas Partai Politik Dan Elektabilitas Partai Politik : Studi Kasus Pada Partai Politik Peserta Pemilu di Propinsi DIY Tahun 2014. JRAK. 14 (1) : 3140. 